\title{
Antibiotic resistance, plasmid profile, auxotypes and serovars of Neisseria gonorrhoeae strains isolated in Sevilla (Spain)
}

\author{
J C Palomares, M C Lozano, E J Perea
}

\begin{abstract}
The antibiotics resistance pattern, the plasmid profile, the auxotypes and serotypes of 116 Neisseria gonorrhoeae clinical isolates obtained in one year were examined. The incidence of penicillinase producing (PPNG) strains was $12 \%$ (14 strains). The most frequent plasmid pattern was the combination of $4 \cdot 5,2 \cdot 6$ and $24 \cdot 5$ MDa plasmids. The conjugative plasmid of $24.5 \mathrm{MDa}$ showed a high prevalence (32\% of the total strains), and almost all the PPNG strains harboured this plasmid. The strains with the $4.5 \mathrm{MDa}$ plasmid belonged to the auxotypes Pro-, Zero and Pro-Hyx-Ura-, whereas that with the $3.2 \mathrm{MDa}$ plasmid was of auxotype Pro-Hyx-His-. The serotypes Aedih/ Arst (WI serogroup) and Bak/Bropt, Back/ Bropyt and Bak/Bropyt (WII/III serogroup) were predominant.
\end{abstract}

The world-wide prevalence of Neisseria gonorrhoeae, and the emergence of antibiotic resistant strains, both chromosomal and plasmid borne, reinforce the need for epidemiological study of this bacterium and the surveillance of its susceptibility to antibiotics commonly used for therapy.

Today, auxotyping and serotyping seem to be the two methods of choice, as well as the plasmid profiles of the isolated strains, for the study of the epidemiology of this pathogens. ${ }^{1}$ The detection of antibiotic resistance by MICs determination and the study of the genetic basis of resistance are the methods for the surveillance of susceptibility evolution and for a successful treatment. ${ }^{2}$

This paper reports a study of the strains isolated in the city of Sevilla (South of Spain). A total of 116 strains of $N$ gonorrhoeae collected during a year period and isolated from 107 patients attended at the

Department of Microbiology, School of Medicine, University of Sevilla, Sevilla, Spain

J C Palomares, M C Lozano, E J Perea
STD Clinic of the School of Medicine, University of Sevilla, were studied (antibiotic resistance, plasmid profile, auxotype and serotype) to determine the epidemiological characteristics of the isolated strains during a specific time in our area.

\section{Materials and methods}

Gonococcal strains: A total of 116 consecutive clinical isolates of $\mathbf{N}$ gonorrhoeae were studied. The strains were obtained from patients of both sexes (62 heterosexual males, 14 homosexual males and 31 females) attending the Centre for Sexually Transmitted Diseases in Sevilla between July 1986 and July 1987.

The isolates were obtained from samples of the following anatomical sites: 78 from the urethra $(67 \%), 33$ from the endocervix (28.5\%), (in 2 women a second strain was isolated in the test-of-cure after 7 days. In both cases it was interpreted as re-infection as both of them were prostitutes and the strains do not show resistance to any antimicrobial.), four from the rectum $(3.5 \%)$ and one from the pharynx $(1 \%)$. They were inoculated in modified Thayer-Martin agar and incubated at $37^{\circ} \mathrm{C}$ in $5 \% \mathrm{CO}_{2}$ for 48 hours. The colonies suspected to be $N$ gonorrhoeae were confirmed by standard procedures, including colony morphology, Gram strain, oxidase test and sugar utilisation pattern, ${ }^{3}$ and monoclonal coagglutination (Phadebact Monoclonal GC test, Pharmacia Diagnostics, Uppsala, Sweden). They were screened for B-lactamase production by the chromogenic cephalosporin test described by Bae et al. ${ }^{4}$

Susceptibility testing: Minimum inhibitory concentrations (MICs) were determined in triplicate without any significative difference by the agar dilution method using Diagnostic Sensitivity Test Agar supplemented with $1 \%$ saponin and $5 \%$ sterile horse blood. The antibiotics used were: penicillin, ceftriaxone, tetracycline, spectinomycin, erythromycin, ofloxacin and ciprofloxacin. Serial two fold antibiotic concentrations ranged from 0.00045 to $64 \mathrm{mg} / \mathrm{l}$, and an antibiotic-free control plate was used in each assay. The plates were incubated at $37^{\circ} \mathrm{C}$ in a $5 \% \mathrm{CO}_{2}$ incubator for $48 \mathrm{~h}$ and the MICs taken as the lowest concentration of antibiotics which gave no growth or a single colony (as seen by the naked eye). $N$ 
Table 1 Susceptibility of 116 N gonorrhoae isolates (14 PPNG and 102 Non-PPNG) to antimicrobial agents

\begin{tabular}{|c|c|c|c|c|c|c|c|c|c|c|c|c|c|c|c|c|c|}
\hline & & Cumulati & ive $\%$ of & olates sus & eptible to & he follow & gg concn & $(m g / l)$ & & & & & & & & & \\
\hline & PPNG & 0.00045 & 0.0009 & 0.0018 & 0.0037 & 0.0075 & 0.015 & 0.03 & 0.06 & $0 \cdot 12$ & $0 \cdot 25$ & 0.5 & 1 & 2 & 4 & 8 & 16 \\
\hline Penicillin & \pm & & & & & & 8 & 23 & 68 & 93 & 97 & 99 & & 100 & 43 & $\star^{93 \star}$ & 100 \\
\hline Tetracycline & $\stackrel{+}{-}$ & & & & & & & & & & , 1 & 5 & 63 & $\begin{array}{l}43 \\
99\end{array}$ & $\begin{array}{r}79^{\star} \\
100^{\star}\end{array}$ & 100 & \\
\hline Spectinomycin & $\stackrel{+}{-}$ & & & & & & & & & & & & & & & 29 & $\begin{array}{l}100 \\
100\end{array}$ \\
\hline Erythromycin & \pm & & & & & & 5 & $\begin{array}{r}7 \\
24\end{array}$ & $\begin{array}{l}79 \\
78\end{array}$ & $\begin{array}{l}93 \\
97\end{array}$ & $\begin{array}{l}100 \\
100\end{array}$ & & ᄎ & & & & \\
\hline Ceftriaxone & $\stackrel{+}{-}$ & 1 & $\begin{array}{r}14 \\
9\end{array}$ & $\begin{array}{l}57 \\
46\end{array}$ & $\begin{array}{l}86 \\
94\end{array}$ & $\begin{array}{l}100 \\
100\end{array}$ & & & & & & & & & & & \\
\hline Ciprofloxacin & $\stackrel{+}{-}$ & & $\begin{array}{l}14 \\
31\end{array}$ & $\begin{array}{l}79 \\
64\end{array}$ & $\begin{array}{r}100 \\
92\end{array}$ & 96 & & 100 & & & & & & $\star$ & & & \\
\hline Ofloxacin & $\stackrel{+}{-}$ & & & & & 2 & $\begin{array}{l}21 \\
51\end{array}$ & $\begin{array}{r}100 \\
94\end{array}$ & 95 & 98 & 100 & & & $\begin{array}{l}\star \\
\star \\
\star\end{array}$ & & & \\
\hline
\end{tabular}

^Approximate peak levels following standard STD dosage: Penicillin $8 \mathrm{mg} / \mathrm{l}$; Tetracycline $4 \mathrm{mg} / \mathrm{l}$; Spectinomycin $100 \mathrm{mg} / 1$; Erythromycin 2 ipg/1 Ceftriaxone $50 \mathrm{mg} / \mathrm{l}$; Ciprofloxacin $2 \mathrm{mg} / 1$; Ofloxacin $2 \mathrm{mg} / \mathrm{l}$.

gonorrhoeae strains of A Reyn (Statens Serum Institut, Copenhagen) were included as control.

Detection of plasmid DNA: Plasmid detection was carried out by agarose gel $(0 \cdot 8 \%)$ electrophoresis as described by T Eckhardt. ${ }^{5}$ The plasmids from Escherichia coli V512 were used in each gel as molecular weight markers.

Auxotyping: The chemically defined media and the technical procedures described by Catlin ${ }^{6}$ were used for auxotyping. In each assay the strains of $N$ gonorrhoeae: ATCC 27628 (non-requiring) ATCC 27630 (Pro- Hyx-) and ATCC 27631 (Pro-metTrip-) were used as controls.

Serotyping: Serological classification into serovars was performed as described by Bygdeman $e t a l$ using two defined sets of monoclonal antibodies, the GS antibodies and the $\mathrm{Ph}$ antibodies provided by $\mathrm{Phar}-$ macia Diagnostics AB, Uppsala, Sweden.

Cell suspensions of $N$ gonorrhoeae U51 (Afegk) and $N$ gonorrhoeae 4412 (Baej) were used as controls.

Statistical analysis: The chi-squared $\left(\chi^{2}\right)$ test was used and confirmed with Fisher's exact test when the sample size was small.

Results

Antibiotic susceptibility: The cumulative percentage

Table 2 Plasmid profile of 116 gonococcal sträins

\begin{tabular}{|c|c|c|c|}
\hline \multicolumn{2}{|c|}{ Non-PPNG strains $(n=102)$} & \multicolumn{2}{|c|}{ PPNF strains $(n=14)$} \\
\hline Plasmid $\star$ & $\begin{array}{l}\text { No of } \\
\text { strains }\end{array}$ & Plasmid ${ }^{\star}$ & $\begin{array}{l}\text { No of } \\
\text { strains }\end{array}$ \\
\hline $\begin{array}{l}2 \cdot 6 \\
2 \cdot 6+7 \cdot 8 \\
2 \cdot 6+24 \cdot 5 \\
2 \cdot 6+7 \cdot 8+24 \cdot 5\end{array}$ & $\begin{array}{r}72 \\
4 \\
24 \\
2\end{array}$ & $\begin{array}{l}2 \cdot 6+4 \cdot 5 \\
2 \cdot 6+3 \cdot 2 \\
2 \cdot 6+4 \cdot 5+24 \cdot 5\end{array}$ & $\begin{array}{r}2 \\
1 \\
11\end{array}$ \\
\hline
\end{tabular}

^Megadaltons. of inhibited strains by the antibiotics studied are shown in table 1 . Over a total of $116 \mathrm{~N}$ gonorrhoeae clinical isolates obtained during a year time period 14 (12\%) were PPNG.

All the antimicrobials had similar activity against the penicillinase producing and non-producing strains, except penicillin and tetracycline. Taken into account the attainable blood levels, the most active were ceftriaxone and ciprofloxacin.

Plasmid profiles: There were no plasmid-free strains in all the series. The plasmid of $2.6 \mathrm{Md}$ was present in all the gonococcal isolates (table 2).

Twenty six non-PPNG strains $(25 \%$ of the total non-producing) and 11 PPNG strains (85\% of the producing ones), carried the conjugative plasmid of $24.5 \mathrm{MDa}$.

Table 3 Auxotypes and serogroups of 116 gonococcal strains

\begin{tabular}{|c|c|c|c|c|}
\hline Group & Auxotype & $\begin{array}{l}\text { WI } \\
\text { strains }\end{array}$ & $\begin{array}{l}\text { WII/III } \\
\text { strains }\end{array}$ & Total \\
\hline PPNG & $\begin{array}{l}\text { Pro- } \\
\text { Pro-Hyx-Ura- } \\
\text { Pro-Hla-Hyx- } \\
\text { Prototrophic }\end{array}$ & $\begin{array}{l}- \\
1(0.8) \\
1(0.8)\end{array}$ & $\begin{array}{l}11(9.4) \\
1(0.8) \\
-\end{array}$ & $\begin{array}{r}11 \\
1 \\
1 \\
1\end{array}$ \\
\hline Non-PPNG & $\begin{array}{l}\text { Pro- } \\
\text { Hyx- } \\
\text { His- } \\
\text { Arg- } \\
\text { Met- } \\
\text { Pro-Ura- } \\
\text { Hyx-Ura- } \\
\text { Pro-Hyx- } \\
\text { Pro-Hyx-Ura- } \\
\left.\text { Pro-Hyx-V-( }{ }^{\star}\right) \\
\text { Pro-His-Hyx- } \\
\text { Pro-Arg-Hyx-Ura- } \\
\text { Prototrophic } \\
\text { Non growing }\end{array}$ & $\begin{array}{l}11(9 \cdot 4) \\
5(4 \cdot 3) \\
= \\
1(0 \cdot 8) \\
= \\
6(5 \cdot 2) \\
2(1 \cdot 7) \\
1(0 \cdot 8) \\
=2(1 \cdot 7) \\
2(1 \cdot 7) \\
2(1 \cdot 7)\end{array}$ & $\begin{array}{c}23(20) \\
13(11) \\
2(1 \cdot 7) \\
1(0 \cdot 8) \\
-2(1 \cdot 7) \\
2(1 \cdot 7) \\
4(3 \cdot 4) \\
1(0 \cdot 8) \\
-2(1 \cdot 7) \\
\frac{15}{15}(13) \\
5(4 \cdot 3)\end{array}$ & $\begin{array}{r}34 \\
18 \\
2 \\
1 \\
1 \\
2 \\
2 \\
10 \\
3 \\
1 \\
2 \\
2 \\
17 \\
7\end{array}$ \\
\hline
\end{tabular}

*Requirement of NAD, thiamine, calcium pantothenate, choline, bio-inositol Biotin, Cocarboxilase, Haemine, L-histidine and $2,2^{\prime}, 2^{\prime \prime}$-nitrilotreithanol. 


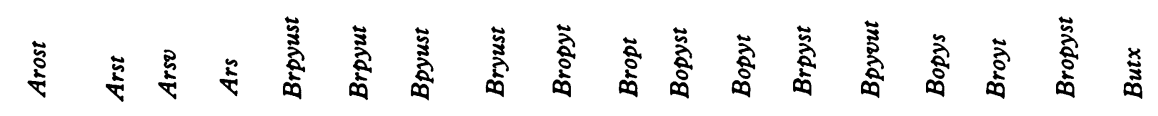

\begin{tabular}{lrrrr}
\hline WI strains & & & \\
Aedgkih & 5 & & \\
Adgkih & 4 & & \\
Aedih & & 18 & \\
Afd & & 2 & 1 \\
Afe & & & 1 \\
Af & & 1 & 2 \\
Adih & & &
\end{tabular}

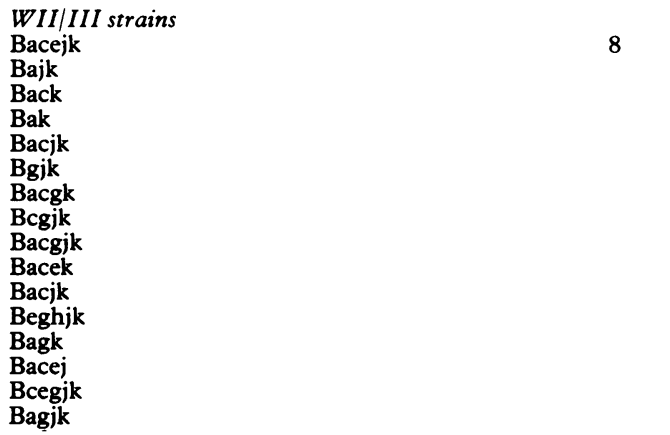

The penicillinase plasmid of $4.5 \mathrm{Md}$ (Asian type) was the more frequent, and only one strain harboured the $3.2 \mathrm{Md}$ (African type), making a total of 14 PPNG strains ( $12 \%$ of total gonococcal isolates). Auxotypes: The auxotypes of the 116 strains are shown in table 3, together with their frequencies.

The Pro- auxotype was the more frequent in both populations, followed by that of the wild type strains (Prototrophic) and the Hyx- in the non-PPNG strains.

Serotypes: The serogroups of the strains are shown in table 3. The serogroup WII/III was the predominant one in the PPNG (86\%) and non-PPNG (69\%) populations.

Table 5 Plasmid profile, auxotype, serogroup and serotype of 14 PPNG strains

\begin{tabular}{|c|c|c|c|c|}
\hline $\begin{array}{l}\text { Plasmid } \\
\text { profile }\end{array}$ & Auxotype & Serogroup & $\begin{array}{l}\text { GS } \\
\text { Serotype }\end{array}$ & $\begin{array}{l}\text { Ph } \\
\text { Serotype }\end{array}$ \\
\hline $\begin{array}{l}2 \cdot 6 ; 4 \cdot 5 ; 24 \cdot 5 \\
2 \cdot 6 ; 4 \cdot 5 ; 24 \cdot 5 \\
2 \cdot 6 ; 4 \cdot 5 ; 24 \cdot 5 \\
2 \cdot 6 ; 4 \cdot 5 ; 24 \cdot 5 \\
2 \cdot 6 ; 4 \cdot 5 ; 24 \cdot 5 \\
2 \cdot 6 ; 4 \cdot 5 ; 24 \cdot 5 \\
2 \cdot 6 ; 4 \cdot 5 ; 24 \cdot 5 \\
2 \cdot 6 ; 4 \cdot 5 ; 24 \cdot 5 \\
2 \cdot 6 ; 4 \cdot 5 ; 24 \cdot 5 \\
2 \cdot 6 ; 4 \cdot 5 ; 24 \cdot 5 \\
2 \cdot 6 ; 4 \cdot 5 ; 24 \cdot 5 \\
2 \cdot 6 ; 4 \cdot 5 \\
2 \cdot 6 ; 4 \cdot 5 \\
2 \cdot 6 ; 3 \cdot 2\end{array}$ & $\begin{array}{l}\text { Pro- } \\
\text { Pro- } \\
\text { Pro- } \\
\text { Pro- } \\
\text { Pro- } \\
\text { Pro- } \\
\text { Pro- } \\
\text { Pro- } \\
\text { Pro-Hyx-Ura- } \\
\text { Pro- } \\
\text { Pro- } \\
\text { Pro- } \\
\text { Prototrophic } \\
\text { Pro-Hyx-His }\end{array}$ & $\begin{array}{l}\text { WII/III } \\
\text { WII/III } \\
\text { WII/III } \\
\text { WII/III } \\
\text { WII/III } \\
\text { WII/III } \\
\text { WII/III } \\
\text { WII/III } \\
\text { WII/III } \\
\text { WII/III } \\
\text { WII/III } \\
\text { WII/III } \\
\text { WI } \\
\text { WI }\end{array}$ & $\begin{array}{l}\text { Bak } \\
\text { Bak } \\
\text { Bak } \\
\text { Back } \\
\text { Back } \\
\text { Back } \\
\text { Back } \\
\text { Back } \\
\text { Back } \\
\text { Bcegik } \\
\text { Bcegjk } \\
\text { Bacejk } \\
\text { Aedgkih } \\
\text { Aedih }\end{array}$ & $\begin{array}{l}\text { Bropyt } \\
\text { Broyt } \\
\text { Broyt } \\
\text { Bropyt } \\
\text { Bropyt } \\
\text { Bropyt } \\
\text { Bropyt } \\
\text { Bropyt } \\
\text { Bropyt } \\
\text { Bpyust } \\
\text { Bpyust } \\
\text { Brpyust } \\
\text { Arost } \\
\text { Arst }\end{array}$ \\
\hline
\end{tabular}

In table 4 are shown the serotypes of the strains. In the serogroup WI, eight serotypes were found, being the Aedih/Arst the more common. In the serogroup WII/III, there were 23 serotypes and the predominants were Bajk/Bropt, Back/Bropyt and Bak/Bropyt. Relationships between plasmids, auxotypes, and serotypes: Table 5 summarises the plasmid, auxotype, serogroup and serotype profiles of the 14 PPNG strains isolated. As can be seen, most of them carried the $4.5 \mathrm{Md}$ plasmid and belonged to the serogroup WII/III and auxotype Pro-. The only one bearing the plasmid of $3.2 \mathrm{MD}$ belonged to serogroup WI and to the auxotype Pro-His-Hyx-.

There were 29 strains (of 37 harbouring it), bearing the conjugative plasmid that required Pro-. The same phenomenon was observed with the plasmid of $4.5 \mathrm{Md}$ (12 strains were of the auxotype Profrom a total of 13). There was no association between plasmid contents and any one of the serotypes.

\section{Discussion}

The 116 gonococcal strains represent all the strains isolated in the STD clinic during that period. They came from $11 \%$ of all the patients attending our clinic. Although in the last year two new STD clinics started to work in Sevilla, probably most of the patients seek treatment by private general practitioners. Some of them could attend our clinic after treatment failure, but we are unable to determine how many.

The strains were isolated between July 1986 and 
July 1987, and no strain showed resistance to spectinomycin or tetracycline, as has been recently described. ${ }^{89}$ The percentage of penicillin resistance chromosomally mediated (MIC $1 \mathrm{mg} / \mathrm{l}$ ) was $1 \%$ and that of penicillin moderately resistant, (MIC between 0.06 and $0.25 \mathrm{mg} / \mathrm{l})^{2} 76 \%$, a figure similar to data obtained in other European countries. ${ }^{10}$ Ceftriaxone and ciprofloxacin are the more plausible alternative treatments for gonococcal infections.

The presence of the $2.6 \mathrm{Md}$ plasmid in all the isolated strains could be the consequence of using only selective medium, as some authors have stated that this plasmid could be associated with vancomycin resistance. ${ }^{11}$ Fourteen strains were penicillinase producers, a $12 \%$ of the total isolated strains. Other authors in different areas of Spain have shown a similar or higher incidence of PPNG strains. ${ }^{1213}$ Thus, the use of penicillin for primary treatment of a gonococcal infection acquired in Spain should not be recommended.

The more prevalent plasmid in these PPNG strains was that of $4.5 \mathrm{Md}$ (12 of 13 strains), but the presence of a strain with that of $3.2 \mathrm{Md}$ shows the possibility of having a mixed population of PPNG strains in our geographical zone, as all the strains were reported to be acquired in Sevilla.

The conjugative plasmid was present in 37 strains $(32 \%)$, a higher incidence than in other areas, where it is estimated to be $20 \%$. Almost all the PPNG strains harboured this plasmid. These results differ from those of other countries with incidences from 20 to $40 \% \cdot{ }^{13-15}$ These data suggest a rapid increase of the PPNG proportion in Sevilla in the future.

Other reports have shown that the $4.5 \mathrm{Md}$ penicillinase plasmid is frequently associated with a requirement for proline. ${ }^{14}{ }^{16}$ Our figure of 11 strains of 14 is similar. The incidence of the Pro- auxotype been only $29 \%$ in the non-PPNG population. A similar association is found between this plasmid, and the serogroup WII/III ${ }^{17}$; of the 13 strains with the $4.5 \mathrm{Md}, 12$ belonged to WII/III sergroup.

There was a significant association $(p \leqslant 0.0096)$ between the conjugative plasmid and the auxotype Pro-; 29 strains of the 37 bearing the plasmid required this aminoacid.

All these data suggest a clear capacity of the strains Pro- to harbour plasmids and propagate them in the gonococcal population.

From our data could it also be deduced that there is a wide variety of serotypes of strains in the area of Sevilla, but the serotypes Aedih/Arst in the WI serogroup and those of Bak/Bropt, Back/Bropyt or Bak/Bropyt in the WII/III serogroup, predominate. This pattern is very similar to that found by other authors. ${ }^{18}$ One strains, Pro-Hyx-V-, was isolated in this study but no other similar strain has been found after that and we do not know the exact meaning of this rare isolate. Nevertheless, our data differ from those of other authors in the PPNG group, where the serotype Back/Bropyt is more frequent in the Prostrains than serotype Bak/Bropyt, thus showing, perhaps, a different epidemiology of the strains in both geographical areas. No epidemiological links were found between these Back/Bropyt strains.

All these data show clearly that the gonococcal population varies from place to place. This should persuade us to perform an epidemiological surveillance specially of antibiotic resistance (not only penicillinase production), in order to avoid treatment failures, and the propagation of resistant strains.

Address for correspondence: Dr J C Palomares, Department of Microbiology, School of Medicine, University of Sevilla, Apdo 914, 41080, Sevilla, Spain

1 Ansink-Schipper MC, Huiskeshoven MH, Wousdtra RK, et al. Epidemiology of PPNG infections in Amsterdam. $\mathrm{Br} \mathrm{J}$ Venereal Dis 1984;60:23-28.

2 Antibiotic Resistance Strains of Neisseria gonorrhoeae. Morbidity and Mortality Weekly Report. Boston, 1987:86(5S).

3 Hall WH, Schierl EA, Maccani JE. Comparative susceptibility of penicillinase-positive and negative Neisseria gonorrhoeae to 30 antibiotics. Antimicrob Agents Chemother 1979;15:562-7.

4 Bae BH, Ledesma G, Korzis J. Analysis of Neisseria gonorrhoeae for In situ B-lactamase production by reagent-impregnated filter paper replica methods. J Clin Microbiol 1983;19:545-7.

5 Eckhardt T. A rapid method for the identification of plasmid deoxyribonucleic acid in bacteria. Plasmid 1978;1:584-7.

6 Catlin BW. Characteristics and auxotyping of Neisseria gonorrhoeae. In: Bergan T, Norris JR, eds. Methods in Microbiology. London: Academic Press, 1978;10:345-80.

7 Bygdeman SM, Gillenius EC, Sandström EG. A comparison between two differents sets of monoclonal antibodies for the serological classification of Neisseria gonorrhoeae. In: Schoolnik GK, Books G, Falkow S, Knapp JS, McCutchan A, Morse $\mathrm{S}$, eds. The Pathogenic Neisseriae. Washington DC: American Society of Microbiology, 1985;11:15-20.

8 Knapp JS, Zenilman JM, Biddle JW, Perkins GH, DeWitt WE, Thomas ML, Johnson SR, Morse SA. Frequency and distribution in the United States of strains of Neisseria gonorrhoeae with plasmid-mediated, high-level resistance to tetracyline. $J$ Infect Dis 1987;155:819-22.

9 Zenilman JM, Nims LJ, Menequs MA, Nolte F, Knapp JS. Spectinomycin-resistant gonococcal infections in the United States, 1985-6. J Infect Dis 1987;156:1002-4.

10 Korking HC, Ramsaroop V. Susceptibility of Neisseria gonorrhoeae to ceftizoxime in vitro and in vivo. Chemotherapy 1984;30:322-6.

11 Miller AA, Anderson P, Parker JW, Hugh Rohrer H. Vancomycin resistance of Neisseria gonorrhoeae isolates by Martin-Lewis Medium. Br J Venereal Dis 1982;58:96-100.

12 Perez JL, Matas E, Marne C, et al. Incremento en la incidencia de gonococos productores de beta-lactamasa en hospitales comarcales de Cataluña. Enfermedades Infecciosas $y$ Microbiología Clinica. 1987;5:99-102.

13 Brezmes MF, Andrés MJ, Pascual PP, Hernandez-Gajate JM, Alberte A, Gomez A, Torio R. Gonococcos productores de beta-lactamasa: incidenciia en nuestro medio. Revista Española de Microbiologia Clínica. 1989;4:31-4.

14 Roberts M, Piot P, Falkow S. The ecology of gonococcal plasmids. J Gen Microbiol 1979;114:491-4.

15 Mavrommati L, Tzelepi E, Sima A, Tzanakaki G, Kokla A, Flemetakis A. Antibiotic resistance, plasmid content and auxotypes of Neisseria gonorrhoeae in Greece. J Antimicrob Chemother 1988;21:571-9.

16 Mee BJ, Turbett G, Rich G. The epidemiology of Neisseria gonorrhoeae isolates from Western Australia based on antibiotic resistance and plasmid profiles. Antimicrob Chemother 1988;21:117-24.

17 Ansink-Schipper MC, van Klingeren B, Huikeshoven MH, Woudstra RK, Dessenskroon $M$, van Wijngaarden LJ. Epidemiology of PPNG infections in the Netherlands: Analysis by auxongraphic typing and plasmid identification. Br J Venereal Dis 1984;60:141-6.

18 Anskink-Schipper MC, Bygdeman SM, van Klingeren B, Sandström EG. Serovars, auxotypes and plasmid profiles of PPNG strains with Asian type plasmid isolated in Amsterdam. Genitourin Med 1988;64:152-5. 